\title{
REVIEW
}

\section{An assessment of the effects of diatoms on planktonic copepods}

\author{
G.-A. Paffenhöfer* \\ Skidaway Institute of Oceanography, 10 Ocean Science Circle, Savannah, Georgia 31411, USA
}

\begin{abstract}
Various studies during the past 8 yr have revealed that numerous species of diatoms, especially at bloom concentrations, can negatively affect the viability of eggs and the condition of nauplii of calanoid copepods. This has been observed during in situ and experimental investigations. Other in situ and experimental studies found no negative effects on reproduction rates and egg viability. Here an attempt is made to evaluate these different findings; in addition, consideration is given to future studies, and several hypotheses are formulated.
\end{abstract}

KEY WORDS: Diatoms · Planktonic copepods · Egg viability

Unicellular mixo- and autotrophs in the ocean transfer energy from the sun into growth/production. A large percentage of this primary production occurs in diatoms, which are found in every geographic region of our oceans. They can have various fates: sinking to the seafloor and being eaten or decaying there, and in the water column being utilized by protozoa or metazoa. Among the main consumers of diatoms are planktonic (mainly calanoid) copepods of all feeding stages. Other major groups of copepods, such as Oithonida and Poecilostomatoida, do not (Uchima \& Hirano 1986 for Oithona davisae) or rarely ingest diatoms (e.g. Turner 1986).

The main consumers of diatoms are numerous species and stages of calanoid copepods, from first-feeding nauplii-usually N III-to adults. Diatoms occur abundantly in cooler climates during certain seasons, mainly in late winter to early spring. They also can occur abundantly in warmer climates in coastal regions, during part or most of the year, and in upwelling regions. Since 1993 diatoms have been thoroughly evaluated concerning their quality as food for marine calanoid copepods (Tables $1 \& 2$ ). Several of the results

\footnotetext{
*E-mail: cmp@skio.peachnet.edu
}

indicated negative effects, mainly on egg viability. It is the goal of this paper to revisit those findings, compare them with those reporting positive effects, and suggest ways to investigate and clarify uncertainties about the effects of diatoms on the lives of calanoid copepods.

In situ studies. The in situ quantifications, i.e. offering environmental particulate matter to calanoid copepods, were conducted over periods of several months to more than $1 \mathrm{yr}$ (Table 1). The initial study by Ianora \& Poulet (1993), which also had a laboratory component (see Table 2), resulted in a lowest egg viability during March and April, which led to the thought that diatoms may not be beneficial for the reproduction of calanoid copepods. Subsequent in situ studies which involved the initial authors (Laabir et al. 1995, 1998) at least partly corroborated the idea that diatoms could reduce egg viability. Laabir et al. (1998) presented clear evidence of interannual variability in egg viability between 1993 and 1994 off Plymouth, UK (their Fig. 3). Observations by Miralto et al. (1999) in the northern Adriatic Sea revealed extremely low egg viability for Acartia clausi and Calanus helgolandicus in the presence of the diatoms Pseudo-nitzschia delicatissima and Skeletonema costatum (Table 1), with a significant correlation between egg mortality and diatom concentration. They indicated aldehydes as potential 
Table 1. Variables of copepod reproduction from in situ studies. A range and/or mean are given for fecundity and viability

\begin{tabular}{|c|c|c|c|c|c|c|c|}
\hline $\begin{array}{l}\text { Species } \\
\text { abundance }\end{array}$ & Food type & Food & $\begin{array}{c}\text { Fecundity } \\
\left(\text { eggs female }{ }^{-1} \mathrm{~d}^{-1}\right)\end{array}$ & $\begin{array}{l}\text { Viability } \\
\text { (\%) }\end{array}$ & $\begin{array}{l}\text { Reproduction } \\
\text { longevity }\end{array}$ & Source & Comments \\
\hline Temora stylifera & $\begin{array}{l}\text { Natural } \\
\text { suspension } \\
<40 \mu \mathrm{m}\end{array}$ & $\begin{array}{l}0.01-0.06 \\
\mathrm{mg} \mathrm{chl} a \mathrm{~m}^{-2}\end{array}$ & $\begin{array}{c}15-105 \\
50.9\end{array}$ & $\begin{array}{l}45-95 \\
77.3\end{array}$ & Unknown & $\begin{array}{c}\text { Ianora \& } \\
\text { Poulet (1993) }\end{array}$ & $\begin{array}{c}\text { Aug 1989- } \\
\text { Jan/Apr } \\
1991\end{array}$ \\
\hline $\begin{array}{l}\text { Calanus helgo- } \\
\text { landicus }\end{array}$ & $\begin{array}{l}\text { Natural } \\
\text { suspension }\end{array}$ & $\begin{array}{l}0.4-2.0 \\
\mu g \operatorname{chl} a l^{-1}\end{array}$ & 6.6 & $\begin{array}{l}24-90 \\
70\end{array}$ & $\begin{array}{c}\text { Unknown } \\
24 \mathrm{~h}(?) \\
\text { For each female }\end{array}$ & $\begin{array}{l}\text { Laabir et al. } \\
\text { (1995) }\end{array}$ & $\begin{array}{c}\text { Feb-Nov } \\
1993\end{array}$ \\
\hline C. helgolandicus & $\begin{array}{l}\text { Natural } \\
\text { suspension }\end{array}$ & $\begin{array}{l}40-120 \\
\mu g C^{-1}\end{array}$ & $\begin{array}{c}3-33 \\
17\end{array}$ & $\begin{array}{c}74-98 \\
83\end{array}$ & $24 \mathrm{~h}$ & $\begin{array}{l}\text { Pond et al. } \\
\text { (1996) }\end{array}$ & $\begin{array}{c}\text { Jan-Sep } \\
1994\end{array}$ \\
\hline C. helgolandicus & $\begin{array}{l}\text { Natural } \\
\text { suspension }\end{array}$ & $\begin{array}{l}0.23-9.0 \\
\mu g \operatorname{chl}^{2} \mathrm{l}^{-1}\end{array}$ & $\begin{array}{c}\text { Roscoff } \\
6.6(1993) \\
4.2(1994) \\
\text { Plymouth } \\
17.5(1993) \\
15.0(1994)\end{array}$ & $\begin{array}{c}20-95 \\
70.2(1993) \\
98.9(1994) \\
\\
25-100(1993) \\
71.3(1993) \\
74-98(1994) \\
83.4\end{array}$ & $24 \mathrm{~h}$ & $\begin{array}{l}\text { Laabir et al. } \\
\text { (1998) }\end{array}$ & $\begin{array}{l}\text { Jan } 1993- \\
\text { Dec } 1994\end{array}$ \\
\hline Acartia clausi & $\begin{array}{l}\text { Natural } \\
\text { suspension } \\
\text { Skeletonema } \\
\text { costatum } \\
\text { Pseudo-nitzschia } \\
\text { delicatissima }\end{array}$ & $\begin{array}{l}0.4-0.8 \times 10^{3} \\
\text { cells ml }\end{array}$ & $11-12$ & 12 & & $\begin{array}{l}\text { Miralto } \\
\text { et al. } \\
(1999)\end{array}$ & 1997 \\
\hline $\begin{array}{l}\text { A. clausi } \\
\text { C. helgolandicus }\end{array}$ & P. delicatissima & $\begin{array}{l}0.4-0.6 \times 10^{3} \\
\text { cells ml }\end{array}$ & $\begin{array}{c}7-12 \\
9.9\end{array}$ & $\begin{array}{c}24 \\
11.6\end{array}$ & & & 1998 \\
\hline
\end{tabular}

agents of antimitotic effects. In relation to this, Pohnert (2000) reported that the diatom Thalassiosira rotula produced 2 of those aldehydes within minutes of being damaged. This indicated that diatoms could release such secondary metabolites as a result of breakage during the copepod feeding process.

The 9 mo study by Pond et al. (1996) showed none of the variability of egg viability reported by the previous authors. Here egg viability ranged from a minimum of $74 \%$ to a maximum of $98 \%$. Their study partly overlapped with that of Laabir et al. (1998), who also observed $>70 \%$ egg viability for Calanus helgolandicus off Plymouth. For Calanus finmarchicus, hatching success had an average of 80 to $90 \%$ from May to October 1995-98 in the St. Lawrence Estuary, and was 80 to $95 \%$ in the Gulf of St. Lawrence during June 1997 (Joly \& Runge 2000). Despite a high abundance of diatoms, food quality in the St. Lawrence Estuary appeared to be excellent for $C$. finmarchicus reproduction. An interannual study on in situ egg production and hatching success of Pseudocalanus newmani off Hokkaido, Japan, led the authors to the conclusion 'that neither clutch size nor egg viability are directly affected by diatom biomass' (Ban et al. 2000).

The age of a female could affect its reproductive performance. The age of copepod females collected from the ocean cannot be quantified unless they belong to those genera which are only fertilized once. If such a female is carrying a spermatophore one can be quite certain that it had just moulted to adulthood (e.g. Paffenhöfer 1970).

Experimental observations. Experimental studies on the effects of diatoms on fecundity and egg viability of calanoid copepods repeatedly included dinoflagellates for comparison (Table 2). Most of the studies cited had phytoplankton concentrations which by far exceeded those encountered in the previously mentioned in situ studies. At such high concentrations egg viability and female longevity of Temora stylifera were negatively affected by the diatom Thalassiosira rotula (Ianora \& Poulet 1993, Table 2). This study provided the initial information on the probable negative effects of diatoms on calanoid reproduction. Similar negative effects on the egg viability of Calanus pacificus were found with 3 different diatom species (Uye 1996). A concerted effort by 23 investigators (Ban et al. 1997), studying 16 copepod species with 17 species of diatoms, revealed 4 different types of effect of diatoms on copepods: (1) diatoms reduced fecundity and hatching; (2) diatoms reduced fecundity but not hatching; (3) diatoms did not reduce fecundity but affected hatching; (4) diatoms did not reduce either of the two. The latter observation was 
Table 2. Variables of copepod reproduction from experimental studies. A range and/or a mean are given for fecundity and viability

\begin{tabular}{|c|c|c|c|c|c|c|}
\hline Species & Food type & $\begin{array}{l}\text { Food } \\
\text { abundance }\end{array}$ & $\begin{array}{c}\text { Fecundity } \\
\left(\text { eggs female }{ }^{-1} \mathrm{~d}^{-1}\right)\end{array}$ & $\begin{array}{l}\text { Viability } \\
\text { (\%) }\end{array}$ & $\begin{array}{l}\text { Reproduction } \\
\text { longevity (d) }\end{array}$ & Source \\
\hline $\begin{array}{l}\text { Temora } \\
\text { stylifera }\end{array}$ & $\begin{array}{l}\text { Thalassiosira } \\
\text { rotula } \\
\text { Prorocentrum } \\
\text { micans }\end{array}$ & $\begin{array}{l}2.3-3.8 \times 10^{5} \\
\text { cells ml }{ }^{-1} \\
4.8-8.7 \times 10^{4} \\
\text { cells ml }\end{array}$ & $\begin{array}{l}40 \\
40\end{array}$ & $\begin{array}{l}25 \\
75\end{array}$ & $\begin{array}{l}20 \\
30\end{array}$ & $\begin{array}{c}\text { Ianora \& } \\
\text { Poulet (1993) }\end{array}$ \\
\hline $\begin{array}{l}\text { Calanus } \\
\text { helgolandicus }\end{array}$ & $\begin{array}{l}\text { T. rotula } \\
\text { Phaeodactylum } \\
\text { tricornutum } \\
\text { P. micans }\end{array}$ & $\begin{array}{r}16 \mu \mathrm{gC} \mathrm{l}^{-1} \\
1600 \mu \mathrm{gC} \mathrm{l}^{-1} \\
68 \mu \mathrm{g} \mathrm{C} \mathrm{l}^{-1} \\
680 \mu \mathrm{gC} \mathrm{l} \mathrm{l}^{-1} \\
10.9 \mathrm{mgC} \mathrm{l}^{-1}\end{array}$ & $\begin{array}{c}0-10 \\
1-28 \\
0.5-2 \\
1.5-5.7 \\
7-31\end{array}$ & $\begin{array}{l}\sim 80 \\
\sim 64 \\
\sim 52 \\
\sim 32 \\
\sim 98\end{array}$ & $\begin{array}{c}42 \\
42 \\
30 \\
- \\
36\end{array}$ & $\begin{array}{l}\text { Chaudron } \\
\text { et al. } \\
\text { (1998) }\end{array}$ \\
\hline $\begin{array}{l}\text { Calanus } \\
\text { pacificus }\end{array}$ & $\begin{array}{l}\text { Ditylum brightwellii } \\
\text { Chaetoceros difficilis } \\
\text { Thalassiosira weissflogii } \\
\text { P. micans }\end{array}$ & $\begin{array}{l}2.6-3.9 \\
\mathrm{mgC}^{-1}\end{array}$ & $\begin{array}{l}\sim 40 \text { to } \sim 95 \\
\sim 20 \text { to } \sim 65\end{array}$ & $\begin{array}{l}\text { Near-zero } \\
\text { to } \sim 40 \\
96.6\end{array}$ & $\begin{array}{l}18=\text { length of } \\
\text { experiments }\end{array}$ & Uye (1996) \\
\hline $\begin{array}{l}16 \text { copepod } \\
\text { species }\end{array}$ & $\begin{array}{l}17 \text { diatom } \\
\text { species }\end{array}$ & $\begin{array}{l}10^{2}-10^{5} \\
\text { cells } \mathrm{ml}^{-1}\end{array}$ & $\begin{array}{l}\text { Near end } \\
\text { of study } \\
0.6-6.8\end{array}$ & $\begin{array}{l}\text { Near end } \\
\text { of study } \\
0-90\end{array}$ & $\begin{array}{l}5-40=\text { length } \\
\text { of experiments }\end{array}$ & $\begin{array}{l}\text { Ban et al. } \\
\text { (1997) }\end{array}$ \\
\hline $\begin{array}{l}\text { Calanus } \\
\text { finmarchicus }\end{array}$ & $\begin{array}{l}\text { Thalassiosira } \\
\text { nordenskioldii } \\
\text { Navicula sp. } \\
\text { Chaetoceros debilis } \\
\text { Skeletonema } \\
\text { Costatum } \\
\text { P. micans } \\
\text { Mixture }\end{array}$ & $\begin{array}{l}0.02-2.0 \mathrm{mg} \mathrm{C} \mathrm{l}^{-1} \\
1.3 \mathrm{mg} \mathrm{C} \mathrm{l}^{-1} \\
1.0 \mathrm{mg} \mathrm{C} \mathrm{l}^{-1} \\
1.1 \mathrm{mg} \mathrm{Cl}^{-1} \\
0.9 \mathrm{mg} \mathrm{C} \mathrm{l}^{-1} \\
1.48 \mathrm{mg} \mathrm{Cl}^{-1}\end{array}$ & $\begin{array}{c}2-27 \\
4 \\
2 \\
35 \\
\\
35 \\
20\end{array}$ & $\begin{array}{l}85-30 \\
\\
\sim 30 \\
\sim 86 \\
\sim 79 \\
\\
\sim 78 \\
\sim 75\end{array}$ & 23 & $\begin{array}{l}\text { Starr et al. } \\
\text { (1999) }\end{array}$ \\
\hline $\begin{array}{l}\text { Calanus } \\
\text { helgolandicus/ } \\
\text { pacificus }\end{array}$ & $\begin{array}{l}\text { Lauderia } \\
\text { borealis }\end{array}$ & $\begin{array}{l}\sim 300-400 \\
\mu g \mathrm{~g} \mathrm{l}^{-1}\end{array}$ & $\begin{array}{l}\text { Lab fertilized } \\
44.2 \\
\text { Ocean fertilized } \\
50.4\end{array}$ & $\begin{array}{l}84 \\
77\end{array}$ & $\begin{array}{l}\sim 45 \\
\sim 45\end{array}$ & $\begin{array}{c}\text { Paffenhöfer } \\
\text { (1970) }\end{array}$ \\
\hline
\end{tabular}

made only for the combination C. finmarchicus and Skeletonema costatum. Whereas the previously mentioned efforts usually included diatoms at high abundances only, Chaudron et al. (1998) offered 2 diatom species at different concentrations including that regularly encountered in neritic oceans (Table 2). For both species of diatoms egg viability increased with decreasing diatom concentrations, while fecundity decreased, as seen in previous studies. Even at the lowest diatom concentration, egg viability was below that attained with the dinoflagellate Prorocentrum micans, which was near $95 \%$. The longevity of reproduction appeared to be similar at both cited concentrations of Thalassiosira rotula (Table 2). However, offering the diatom Thalassiosira nordenskioldii, whose size is similar to that of T. rotula at 500 cells ml $^{-1}\left(\sim 80 \mu \mathrm{g} \mathrm{Cl}^{-1}\right)$ resulted in low fecundity of Calanus finmarchicus and a low egg viability of only 10 to $40 \%$ near the end of the study (Ban et al. 1997). This viability level was clearly below that of T. rotula at $\sim 160 \mu \mathrm{g} \mathrm{Cl}^{-1}$ (Chaudron et al. 1998), which was near $65 \%$ over time. These results may indicate a differing severity of effects of different diatom species on egg viability.
Offering separately the diatoms Navicula sp., Thalassiosira nordenskioldii, Skeletonema costatum and Chaetoceros debilis at high concentrations to adult females of Calanus finmarchicus resulted in low egg viability with the former 2 (about $30 \%$ of all eggs were viable, Starr et al. 1999, Table 2) and high viability with the latter 2 (Table 2). With the former 2 diatoms the percentage of non-viable eggs increased over $23 \mathrm{~d}$ to near $70 \%$. In addition, as found by Chaudron et al. (1998), egg viability increased with decreasing food concentration ( $T$. nordenskioldii), eventually to $\sim 85 \%$. Offering 3 diatoms as a mixture ( $T$. nordenskioldii, S. costatum and C. debilis; Table 2) resulted in an increase in the percentage of non-viable eggs/unhealthy nauplii during $23 \mathrm{~d}$ to near $50 \%$. The females had ingested more T. nordenskioldii than the other 2 diatoms put together (Starr et al. 1999). The authors considered that antimitotic agents within cells of diatoms such as Navicula sp. and T. nordenskioldii (see also Poulet et al. 1994) would be effective via accumulation in the oocytes after having been accumulated within the female copepod.

An earlier study in which the diatom Lauderia borealis was offered to spermatophore-carrying females of 
Calanus helgolandicus/pacificus resulted in high reproduction rates and high egg viability of laboratoryand ocean-fertilized copepods (Table 2) during most of the $>40 \mathrm{~d}$ of reproduction (Paffenhöfer 1970). L. borealis concentrations resembled upwelling bloom conditions. The experiments were conducted until the females did not produce any more fertilized eggs. Egg viability was never below $60 \%$, and fecundity decreased during the last $14 \mathrm{~d}$ of fertilized egg production. These findings resemble those of Pond et al. (1996) concerning viability, although during the latter study diatoms did not amount to a high percentage of the total carbon except for 1 time.

In summary, the laboratory studies show that not all diatoms have a pronounced negative effect on copepod egg viability and/or fecundity at high concentrations (e.g. Calanus helgolandicus/pacificus and Lauderia borealis, Paffenhöfer 1970; Calanus finmarchicus and Skeletonema costatum, Ban et al. 1997, Starr et al. 1999).

Thoughts in regard to future studies. Future studies on the relationships of diatoms and copepods should address the following questions:

(1) Do all abundantly occurring diatom species have some negative effects, as individual species or combined, on calanoid copepods, especially reproduction? The study by Ban et al. (1997) seems to indicate that most diatom species studied individually had some negative effects. There, only one combination-Calanus finmarchicus and Skeletonema costatum from the St. Lawrence Estuary as in Starr et al. (1999) - experienced no negative effects on fecundity and egg viability. We should recall that $S$. costatum was the dominant diatom during the spring phytoplankton maximum during which $C$. finmarchicus was growing and reproducing in the Clyde Sea area (Marshall \& Orr 1927). However, S. costatum in the northern Adriatic Sea negatively affected the egg viability of Acartia tonsa (Miralto et al. 1999). Any studies should consider mainly offering those diatom species which occur commonly to abundantly in the regions in which the copepods to be tested occur.

(2) As negative effects occur, which are the variables causing those effects? Chaudron et al. (1998) and Starr et al. (1999) showed that diatom concentration by itself has an effect on egg viability: An increase in food concentration/ingestion resulted in an increase in the percentage of non-viable eggs. This question would require nutritional biochemistry studies which were specifically addressed at a Zooplankton Nutrition Workshop (Kleppel 2002). The demonstrations of (a) hatching viability being positively correlated with the concentrations of 2 unsaturated fatty acids in the eggs and the environment (Pond et al. 1996) and (b) 3 aldehydes within Thalassiosira rotula, Skeletonema costa- tum and Pseudo-nitzschia delicatissima which resulted in low calanoid hatching rates (Miralto et al. 1999) represent early initiatives to quantify chemical compounds associated with reproductive success or failure.

(3) Can calanoids, by eating non-diatom particles and diatoms together, reduce or minimize or remove any negative diatom effects? To answer this question ingestion rates have to be quantified. During the earlier mentioned in situ and experimental reproduction studies (Tables 1 \& 2), there was no quantification of how much of which particle type/species was ingested, except occasionally by Starr et al. (1999). Calanoids are known to choose, and exercising that capability should be beneficial for them. Three studies in which calanoids were offered environmental food spectra revealed that in most cases clearance rates (volume swept clear copepod ${ }^{-1} \mathrm{~h}^{-1}$ ) were higher on heterotrophs than on diatoms (Kleppel 1993, Fessenden \& Cowles 1994, Verity \& Paffenhöfer 1996), even when the heterotrophs were smaller and less abundant than the diatoms (Verity \& Paffenhöfer 1996). Why would it be that calanoids prefer heterotrophs over diatoms when diatoms are abundant? One hypothesis could be that heterotrophs, and also autotroph dinoflagellates, provide compounds which most of the diatoms do not provide/possess. Many calanoid species are assumed to be able to perceive such 'morsels' and preferentially ingest them. Therefore, we ought to quantify-in a multiyear effort-ingestion rates of the abundant environmental food particles by the most common calanoid species simultaneously with quantifying fecundity and egg viability; we should complement this with experimental observations on the effects of the usually found low abundance of heterotrophs in the presence of abundant diatoms on the abovementioned variables.

(4) To what extent will the environment affect the physiological and biochemical processes within the various abundant diatom species, and thus may change their nutritional value? In essence, can environmental variables alter the nutritional value of a diatom or lead to antimitotic metabolites (e.g. Miralto et al. 1999, Pohnert 2000)? For example, cell concentrations of lipid and carbon of the diatom Phaeodactylum tricornutum increased by about $250 \%$ over a period of $5 \mathrm{~d}$ when the cells were nitrogen-starved (Larson \& Rees 1996); carbohydrate levels barely increased. We know from Lee et al. (1971) that wax ester fatty acids of field-collected Calanus helgolandicus/ pacificus were markedly different from those of the same species reared in the laboratory on phytoplankton. We may ask whether a copepod may be able to perceive the differences in nutritional value of a diatom species grown in different regimes. Question (4) could be addressed with a methodology similar to that used to answer question (2). 
(5) Could there be species-specific responses of different copepod species to one or several abundantly occurring diatom species and other food taxa? Whereas the calanoid Temora stylifera readily ingested the diatom Rhizosolenia sp. at environmental concentrations from 5 to $20 \mu \mathrm{gC} \mathrm{l}^{-1}$, the co-occurring calanoid Centropages velificatus (furcatus) ingested the same algal species at $25 \%$ of the former copepod species (Paffenhöfer \& Knowles 1980). It may not be necessarily the food value which determines the actual ingestion but also the morphology of the particle. One could apply the same or similar methodology as applied for question (2).

The preceding paragraphs focused exclusively on calanoid copepods, which are considered major consumers of diatoms and similarly sized autotrophs and heterotrophs. The often co-occurring cyclopoid and poecilostomatoid copepods are not considered to feed heavily on diatoms, although various species of diatoms have been found in fecal pellets of Oithona plumifera and Oncaea venusta (Turner 1986). Among the tunicates, doliolids are able to ingest particles as wide as $50 \mu \mathrm{m}$ (Deibel 1985), which implies that they should be able to ingest smaller diatoms, such as Skeletonema costatum. Abundantly occurring taxa such as doliolids should also be included when addressing some of the abovementioned questions.

Three major hypotheses could be considered:

- From Table 2 one could assume that different diatom species will have different effects on the performance of a single species of calanoid copepod.

- As food for calanoid copepods, a large percentage of marine diatoms are qualitatively sufficient for growth but not for egg viability, optimal fecundity and nauplius condition. Being able to choose/ select food particles may allow juvenile and adult copepods to compensate in most instances for missing/inadequate compounds from ingested diatoms by ingesting food particles which contain such compounds, e.g. mixotrophs and heterotrophs. Thus, ingestion of diatoms plus heterotrophs, or dinoflagellates such as Prorocentrum micans, will result in conditions positive for reproduction, growth and animal condition.

- The effects of antimitotic metabolites could be limited by substantial ingestion of other food species, resulting in decreased ingestion of the harmful diatom species (e.g. Kang \& Poulet 2000).

Acknowledgements. This study was supported by the National Science Foundation (grant OCE 94-15791) and the Department of Energy (grant DE-FG02-92ER61419). Dr Gary S. Kleppel and Dr Adrianna Ianora improved this manuscript with thoughtful and constructive comments. The author gratefully acknowledges their support.

\section{LITERATURE CITED}

Ban S, Burns C, Castel J, Chaudron Y and 19 others (1997) The paradox of diatom-copepod interactions. Mar Ecol Prog Ser 157:287-293

Ban S, Lee HW, Shinada A, Toda T (2000) In situ production and hatching success of the marine copepod Pseudocalanus newmani in Funka Bay and adjacent waters off southwestern Hokkaido, Japan: associated to diatom bloom. J Plankton Res 22:907-922

Chaudron Y, Poulet SA, Laabir M, Ianora A, Miralto A (1998) Is hatching success of copepod eggs density-dependent? Mar Ecol Prog Ser 144:185-193

Deibel D (1985) Blooms of the pelagic tunicate, Dolioletta gegenbauri: Are they associated with Gulf Stream frontal eddies? J Mar Res 43:211-236

Fessenden L, Cowles TJ (1994) Copepod predation on phagotrophic ciliates in Oregon coastal waters. Mar Ecol Prog Ser 107:103-111

Ianora A, Poulet SA (1993) Egg viability in the copepod Temora stylifera. Limnol Oceanogr 38:1615-1626

Joly P, Runge J (2000) Hatching success and viability of early life stages of Calanus finmarchicus in coastal waters of the northwest Atlantic Ocean. Abstract, ASLO Meeting, 5-9 June 2000, Copenhagen

Kang HK, Poulet SA (2000) Reproductive success in Calanus helgolandicus as a function of diet and egg cannibalism. Mar Ecol Prog Ser 201:241-250

Kleppel GS (1993) On the diets of calanoid copepods. Mar Ecol Prog Ser 99:183-195

Kleppel GS (Convener) (2002) Zooplankton Nutrition Workshop, Columbia, SC, 29-30 October 1999. National Science Foundation, Arlington, VA

Laabir M, Poulet SA, Ianora A, Cueff A (1995) Reproduction response of Calanus helgolandicus. II. In situ inhibition of embryonic development. Mar Ecol Prog Ser 129:97-105

Laabir M, Poulet SA, Harris RP, Pond DW, Cueff A, Head RN, Ianora A (1998) Comparative study of the reproduction of Calanus helgolandicus in well-mixed and seasonally stratified waters of the western English Channel. J Plankton Res 20:407-421

Larson TR, Rees TAV (1996) Changes in cell composition and lipid metabolism mediated by sodium and nitrogen availability in the marine diatom Phaeodactylum tricornutum (Bacillariophyceae). J Phycol 32:388-393

Lee RF, Nevenzel JC, Paffenhöfer GA (1971) Importance of wax esters and other lipids in the marine food chain: phytoplankton and copepods. Mar Biol 9:99-108

Marshall SM, Orr AP (1927) The relation of the plankton to some chemical and physical factors in the Clyde Sea area. J Mar Biol Assoc UK 14:837-868

Miralto A, Barone G, Romano G, Poulet SA and 7 others (1999) The insidious effect of diatoms on copepod reproduction. Nature 402:173-176

Paffenhöfer GA (1970) Cultivation of Calanus helgolandicus under controlled conditions. Helgol Wiss Meeresunters 20:346-359

Paffenhöfer GA, Knowles SC (1980) Omnivorousness in marine planktonic copepods. J Plankton Res 2:355-365

Pohnert G (2000) Wound-activated chemical defense in unicellular planktonic algae. Angew Chem Int Ed 39:4352-4354

Pond D, Harris R, Head, Harbour D (1996) Environmental and nutritional factors determining seasonal variability in the fecundity and egg viability of Calanus helgolandicus in coastal waters off Plymouth, UK. Mar Ecol Prog Ser 143: 45-63

Poulet SA, Ianora A, Miralto A, Meijer L (1994) Do diatoms 
arrest embryonic development in copepods? Mar Ecol Prog Ser 111:79-86

Starr M, Runge JA, Therriault JC (1999) Effects of diatom diets on the reproduction of the planktonic copepod Calanus finmarchicus. Sarsia 84:379-389

Turner JT (1986) Zooplankton feeding ecology: contents of fecal pellets of the cyclopoid copepods Oncaea venusta, Corycaeus amazonicus, Oithona plumifera and O. simplex from the northern Gulf of Mexico. PSZN Mar Ecol 7:289-302

Editorial responsibility: Barry \& Evelyn Sherr, (Contributing Editors) Corvallis, Oregon, USA
Uchima M, Hirano R (1986) Food of Oithona davisae (Copepoda: Cyclopoida) and the effect of food concentration at first feeding on the larval growth. Bull Plankton Soc Jpn $33: 21-28$

Uye S (1996) Induction of reproductive failure in the planktonic copepod Calanus pacificus by diatoms. Mar Ecol Prog Ser 133:89-97

Verity PG, Paffenhöfer GA (1996) On assessment of prey ingestion by copepods. J Plankton Res 18:1767-1779

Submitted: May 9, 2001; Accepted: July 9, 2001

Proofs received from author(s): January 25, 2002 